\title{
On the Sustainable Economic Growth in Sub-Saharan Africa: Do Remittances, Human Capital Flight, and Brain Drain Matter?
}

\author{
Mohammed A. M. Usman *(D), Huseyin Ozdeser (D, Behiye Çavuş̧oğlu (D) and Umar Shuaibu Aliyu
}

Citation: Usman, M.A.M.; Ozdeser, H.; Çavuşoğlu, B.; Aliyu, U.S. On the Sustainable Economic Growth in Sub-Saharan Africa: Do Remittances, Human Capital Flight, and Brain Drain Matter? Sustainability 2022, 14, 2117 https://doi.org/10.3390/su14042117 Academic Editor: Andrea Pérez

Received: 5 January 2022 Accepted: 10 February 2022 Published: 12 February 2022

Publisher's Note: MDPI stays neutral with regard to jurisdictional claims in published maps and institutional affiliations.

Copyright: (C) 2022 by the authors. Licensee MDPI, Basel, Switzerland. This article is an open access article distributed under the terms and conditions of the Creative Commons Attribution (CC BY) license (https:// creativecommons.org/licenses/by/ $4.0 /)$.
Department of Economics, Near East University, Boulevard, Nicosia 99138, North Cyprus, Mersin 10, Turkey; Huseyin.ozdeser@neu.edu.tr (H.O.); behiye.cavusoglu@neu.edu.tr (B.Ç.); umar.aliyu@neu.edu.tr (U.S.A.)

* Correspondence: amkmgella@gmail.com

\begin{abstract}
To solve the active macroeconomic challenges of remittances, human capital flight, and brain drain facing Sub-Saharan Africa (SSA) from the perspective of costs and benefits tradeoffs for achieving Sustainable Development Goal eight (SDGs-8) targets by 2030 and the recipient communities' wellbeing, this study investigates the sustainable economic growth in SSA: Do remittances, human capital flight, and brain drain matter? Autoregressive-Distributive Lag (ARDL) and the ErrorCorrection Mechanism (ECM) were used. Thus, this research is led by push-pull, altruism, and social network theories. The ARDL showed that remittances and trade positively affect economic growth. However, human capital flight, poverty, corruption, and inequality negatively affect economic growth. The co-efficient of $\mathrm{ECT}_{\mathrm{t}-1}$ is ascertained to be negative (-0.266282) with a significant statistical value of $1 \%$ (i.e., 0.0123 ). Therefore, the annual requirement to restore equilibrium convergence is $26.62 \%$. The study concludes that SSA may achieve their sustainable economic growth target, particularly by formalizing remittances and human capital flight and brain drain into the financial, economic system in SSA by 2030, since restoration to long-term convergence will take less than nine years. Enabling a labor market that offers decent work and wages, along with trade and remittance policies for sustainable growth, are recommended.
\end{abstract}

Keywords: remittances; human capital flight and brain drain; Economic Growth; Panel ARDL; SSA; SDGs; sustainability

\section{Introduction}

Over the last decade, economies in Sub-Saharan Africa have faced significant and large financial shortfalls, obstructing much-needed public and private investments that will help the region meet Sustainable Development Goal eight (SDGs-8) agreed upon by UN member states in September 2015 in New York. For example, SDG-8 includes fostering sustained social inclusion, productive employment in the form of decent work for all, and an economic growth target that meets at least $7 \%$ growth annually, among others. Thus, this will be a fairytale unless organized measures are implemented to achieve the 2030 target. However, given that the region has been a source of large-scale human capital flight and brain drain for the past 40 years, achieving the SDGs will be an immense task because of the developing nature of SSA member states, particularly those facing acute food scarcity, insufficient infrastructure, income inequality, and a scarcity of capital [1]. Though there are benefits associated with brain drain from remittances to their home countries for consumption and education investments, there was universal agreement that remittances might be used to strengthen the economy.

In 2019, remittances to low- and middle-income countries reached a new high of $\$ 554$ billion (World Bank 2019). Thus, Remittances from the EU and non-OECD nations account for $55 \%$ of global remittances. The United States, Switzerland, Germany, France, and Luxembourg are the top ten receiving countries globally. The estimate will reach $\$ 574$ 
billion by 2020 [2]. Remittances from migrant workers in developed nations, for instance, are gaining importance in developing economies. Until recently, governments and financial markets paid little attention to these transfers because they were in meager amounts. Therefore, due to the outstanding aggregate worth of remittances to many developing economies, particularly African countries, their importance to development has not been ignored in recent years [2].

Similarly, the collective remittances to developing countries were estimated to exceed $\$ 240$ billion in 2007, up from $\$ 31.2$ billion in 1990 [3]. Therefore, overall remittances might be up to $50 \%$ greater than official figures if remittances sent through informal channels are included [4]. However, in SSA, poverty, corruption, and income inequality have increased in recent decades, and they continue to generate a burden on the economy over time [5]. On an individual basis, the reasons for income disparity can be traced back to variations in income and other socio-economic conditions. Differences in human skills, human flight and brain drain, employment, and other factors are among them [6]. These inequalities can be evident nationally, leading to inequity and potentially significant difficulties in SSA African countries. For instance, one-third of Africa's most educated nationals are believed to live outside the continent, primarily in Western Europe and North America [5,7,8]. Zambia, for example, had 1600 medical practitioners a few years ago, but barely 400 are currently working [9,10]. Ghanaian and Zambian doctors have moved to Europe, the United States, and across the African continent, such as Botswana, where earnings are greater, according to the UNDP report of Human Development Study 2015 [11].

Worthy of note is that the speed with which human capital flight is snowballing from SSA is alarming and can be an important indicator for macroeconomic policy effects, especially with respect to providing opportunities in the domestic labor market, jobs, and decent work for all in SSA economies. Therefore, ignoring the consequences on SSA economies may lead to failure to consider its effects on their economic policies.

Thus, the question here is do remittances, human capital flight, and brain drain have any impact on the sustainable economic growth in SSA? Particularly when directed at achieving decent work for all, reasonable wages, access to opportunities, the labor market, and jobs, among other SDGs opportunities in the coming 2030, have rarely been considered by previous studies related to SSA countries, to the best of the researchers' knowledge. Even though a lot of the SSA countries are faced with human capital flight and brain drain challenges, most of the families in SSA depend on remittances from relatives as a means of survival. Accordingly, the research intent is to fill this gap.

Following, the contributions of this research offer evidence for externality effects of informal and social remittances in the form of innovative ideas, democratic values, and attitudes, technical skills, and behaviors of the diasporas towards the SSA to combat problems of human capital flight and brain drain to assist in designing and implementing policies and strategies that can help in improving domestic opportunities and the welfare status of their people. Furthermore, the push-pull theory, altruism, and social network theories contribute and guide the investigation from a theoretical standpoint. Accordingly, the theory of the push-pull factors ascertains that there are three other factors of migration that push or pull migrants out of their native country: Economic, psychological, and situational. A lack of employment prospects and the inability to use skills acquired in the home country are two economic factors. Family reunification and altruism are the psychological push factors, among others. Meanwhile, according to altruism and the social network theory, one of the motives behind individuals immigrating is because it allows them to maximize their prospects as well the connections between individuals, groups, and organizations, be it from knowledge structures (interpersonal relations) or cognitive qualities and behavioral structures. The previous studies hardly incorporated these contributions in their investigations, and this makes our study unique. Lastly, this research qualifies the investigation and examination of remittance, human capital flight, and brain drain in respect to sustainable economic performances, in order for SSA countries to be acknowledged, investigated, and help appropriate experts and institutes to control 
and establish effective programs related to remittances, human capital flight, and brain drain in their economies.

From the foregoing, the objective of this research is to examine the impact of remittances, human capital flight, and brain drain of SSA on the sustainable economic growth (i.e., SDGs target) by the year 2030, which is seldom considered in the extant literature.

Therefore, the study is divided into six sections: The first section deals with the introduction and stylized facts of remittance, human capital flight, and brain drain in SSA; the second section deals with the review of the related literature; the methodology is in the third section; and the results are in the fourth section. Meanwhile, the discussion is in the fifth section. Finally, the sixth section deals with the research conclusion, recommendations, and implications.

\section{Stylized Facts on Remittances, Human Capital Flight, and Brain Drain in the SSA Region}

The top 5 remittance recipients are India ( $\$ 79$ billion), China ( $\$ 67$ billion), Mexico (\$36 billion), the Philippines (\$34 billion), and Nigeria and Egypt (\$29 billion) [12]. The bank has predicted remittance flows to low- and middle-income nations at over $\$ 550$ billion, up from \$529 in 2018 [12]. Remittances from the diaspora play a critical role in sustaining local livelihoods, community development projects, innovation, and entrepreneurship [13,14]. For example, Ugandan, Rwandan, Guinean, Seychelles, and South African imports all rely heavily on remittances, which range from $18 \%$ in Uganda to $1 \%$ in South Africa [15]. Small and fragile states such as Lesotho, Liberia, and Gambia rely heavily on remittances, which account for $20 \%$ of their GDP [15]. Similarly, the African diaspora can boost African exports by generating roughly $\$ 2100$ in additional exports for his or her home nation each year [16] The fact is that global remittances to Sub-Saharan Africa (SSA) increased by $10 \%$ to $\$ 46$ billion in 2018 [6,12], up from $\$ 40$ billion in 2015 [14], while some estimates put informal remittances flows to Africa at twice the official estimate [6,12,14]. For instance, most African countries now rely heavily on international remittances for foreign currency, with private remittances accounting for the majority of international financial flows to Africa [12,17]. This implies that remittances from African diasporas have been more steady, trustworthy, and countercyclical than other kinds of foreign currency inflows, such as Foreign Direct Investment (FDI) and Official Development Assistance (ODA), maintaining consumption and investment throughout recessions. Thus, if one out of every ten diaspora members could be persuaded to invest $\$ 1000$ in their home country, Africa could raise $\$ 3$ billion each year in development funding $[13,14]$.

Apart from financial remittances, African Diasporas are a significant source of social remittance in the form of innovative ideas, democratic values and attitudes, technical skills, behaviors, and civic engagement networks $[18,19]$, all of which are important tools in the development process. Therefore, social remittances are transnational social capital produced through a social and cultural process based on trust and mutuality norms and networks [20].

Despite the fact that migration has been documented as a component of humanity for millennia, people migrate for a variety of reasons, including economic, political, family, educational, medical, career, and the pursuit for greener pastures or a better quality of life, among others [21-23]. This phenomenon is not limited by gender, age, or educational achievement; men and women, young and old, educated and uneducated, all participate in this behavior, although the characteristics and distribution of emigrants vary among countries and regions [24]. It was recently established that youths, including those who are employed, unemployed, or underemployed, have a strong desire to leave their country, particularly those in the SSA countries $[25,26]$. The belief held by both the young and the old is that a good life can only be found outside of one's home country or comfort zone.

Remittances to SSA are set to decline by 12.5 percent to $\$ 42$ billion in 2020, and the decline was almost entirely attributable to a $27.7 \%$ reduction in remittance flows to Nigeria, which accounted for more than $40 \%$ of the region's remittance flows [27]. Excluding Nigeria, remittances to Sub-Saharan Africa grew by 2.3 percent. For instance, a $37 \%$ 
increase was reported in Zambia, 16\% in Mozambique, 9\% in Kenya, and 5\% in Ghana, with the remittances to the region expected to increase by 2.6 percent in 2021, owing to improved development prospects in high-income nations [2]. Data on remittance inflows to Sub-Saharan Africa are scarce and of variable quality, with some countries continuing to use the old Fourth IMF Balance of Payments Manual rather than the Sixth, and others failing to publish any data at all. While the recorded remittances reported by official sources show increased inflows, high-frequency phone surveys in some nations revealed losses in remittances for a large percentage of households [6]. The increase in the volume of remittances recorded by central banks can be explained in part by the transition from informal to legal routes caused by border closures. For example, the highest-receiving recipient region for remittances inflows is Sub-Saharan Africa, whereby sending $\$ 200$ cost an average of 8.2 percent in the fourth quarter of 2020. Sending money from South Africa to Botswana (19.6\%), Zimbabwe (14\%), and Malawi (14\%) is expensive within the region, which has a high intra-regional migration rate (16 percent), according to a press release issued by [28].

Figure 1 depicts the trend of remittance inflow into select SSA countries. Starting from 2006 , the remittance inflow continued to increase from approximately $1.6 \%$ to $2 \%$ until 2008 when it started declining from approximately $2 \%$ to $1.8 \%$ due to the global financial crisis in 2009. The upward trend continued until the last phase of $2019(2.5 \%)$, which shows a tremendous decline from $2.5 \%$ to $2.4 \%$ in 2020 due to the COVID-19 pandemic as forecasted by the World Bank in 2019. The graph depicts the decreased ability to transmit and collect remittance flows through official channels as a result of domestic lockdowns and economic declines, as well as the decreased demand for migrant labor and lower earnings for the same reasons $[29,30]$.

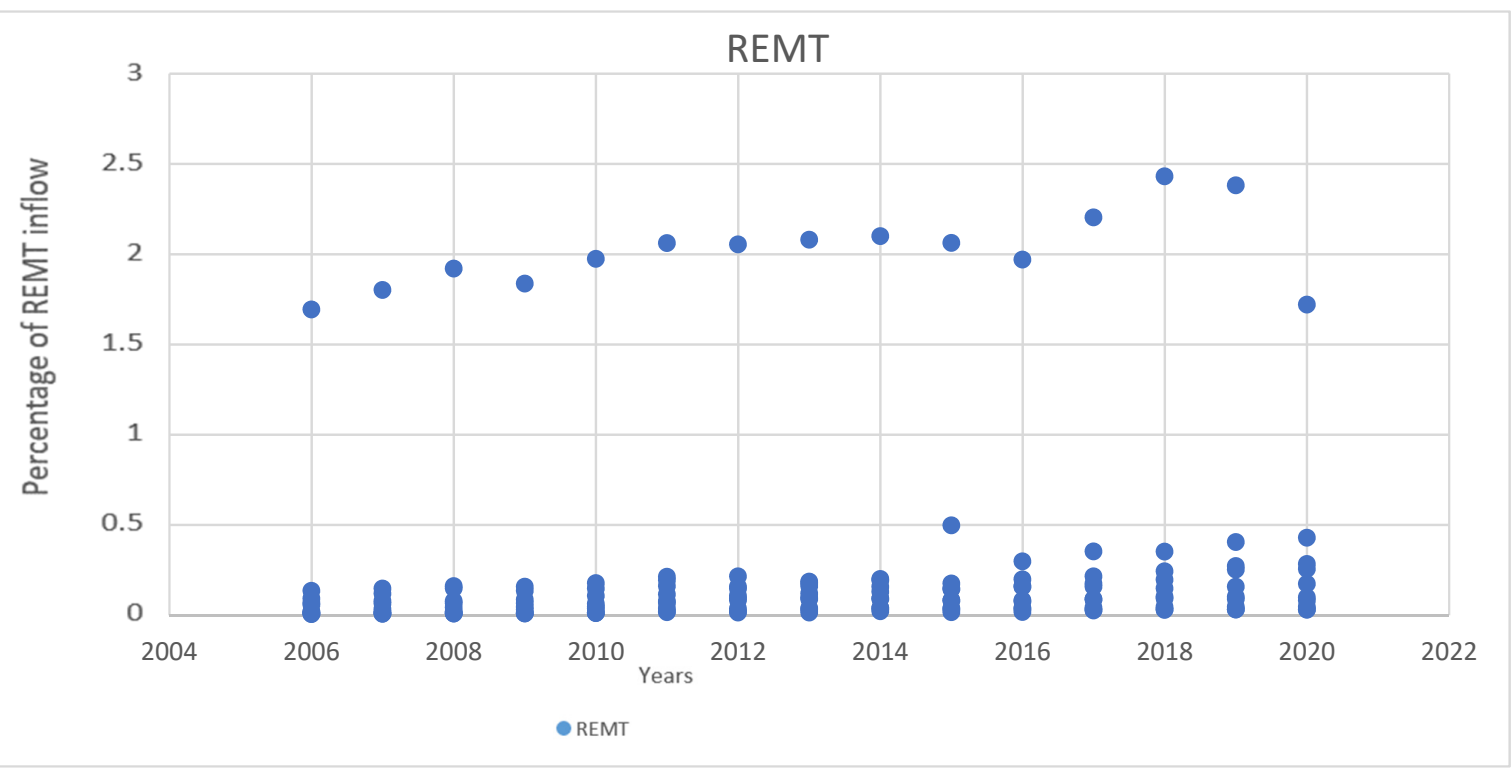

Figure 1. Trend of remittance inflow in select Sub-Saharan African countries.

Similarly, among the selected Sub-Saharan African countries, Nigeria is the highest recipient of remittance inflows as shown in the scale of 3.5\% in the vertical axis of Figure 2. Nigeria received 3\% of the remittance inflow of these selected Sub-Saharan African countries, which is in line with the reported results by [6,12], followed by Ghana at $0.8 \%$, Senegal at $0.7 \%$, Kenya at $0.6 \%$, Somalia at $0.5 \%$, Mali at $0.3 \%$, and South Africa at $0.2 \%$, approximately. Countries with the lowest remittance inflow include Niger, Côte d'Ivoire, and Burkina Faso as depicted in Figure 2. 


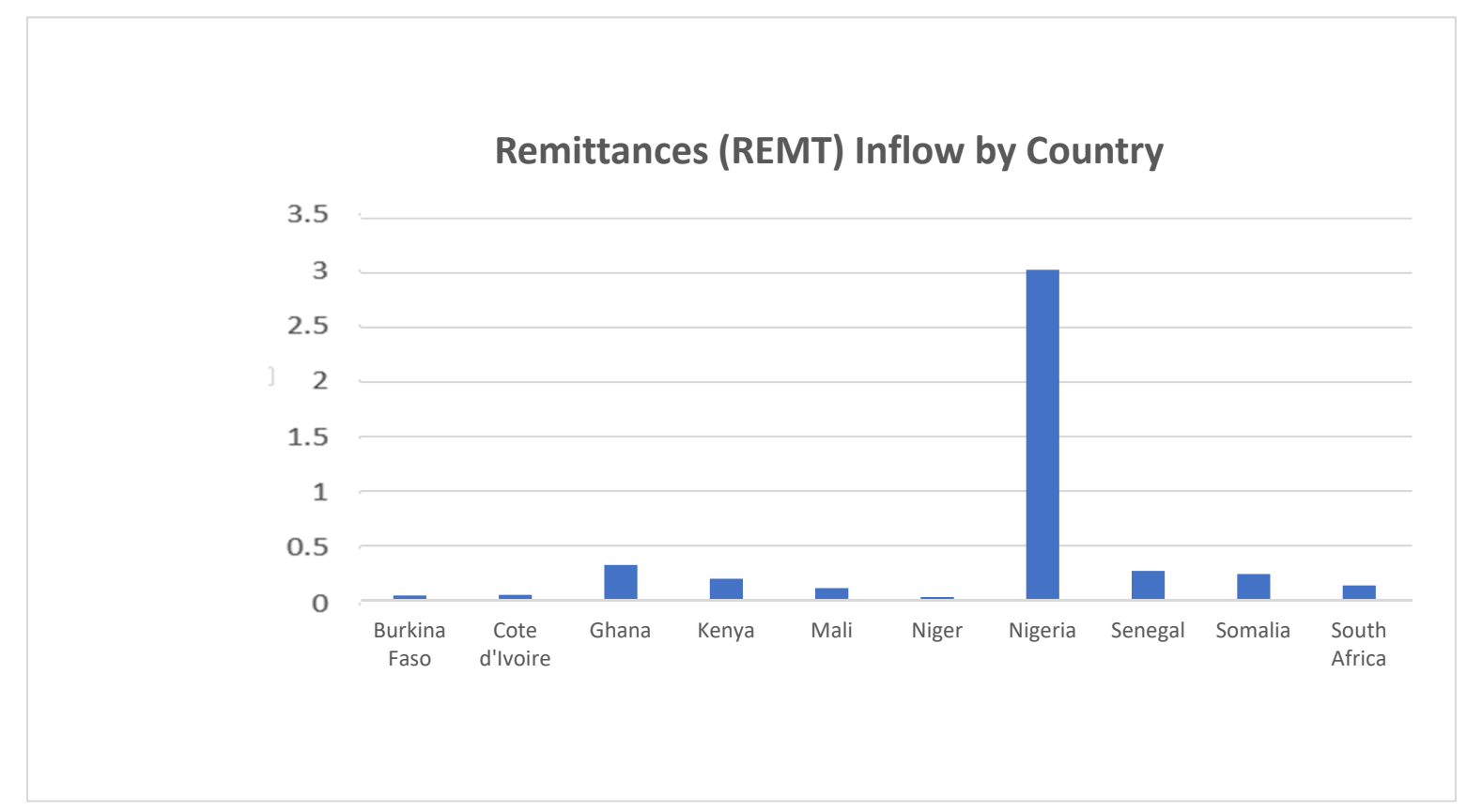

Figure 2. Volume of remittance inflow in the selected Sub-Saharan African countries.

Trend of Human Flight and Brain Drain in Sub-Saharan Africa

International migration has attracted much attention in recent decades: The large inflow of Eastern Europeans toward Western Europe (about 20 million in the last 25 years); the continuous migration from Latin American countries mainly to the United States; and, in the last couple of years, the surge of refugees moving to Europe that has resulted in the ongoing refugee crisis. From Figure 3, one can observe the country that suffers the most in terms of human flight and brain drain is Somalia, which accounted for an annual outflow of more than 1300 migrants, followed by Mali with 1300, Ghana with 1200, Kenya with 1200 , Cote d'Ivoire with 1150, and Nigeria with 1100, approximately. Meanwhile, South Africa is the country that suffers least from human capital flight and brain drain, with an outflow of approximately 700 migrants annually.

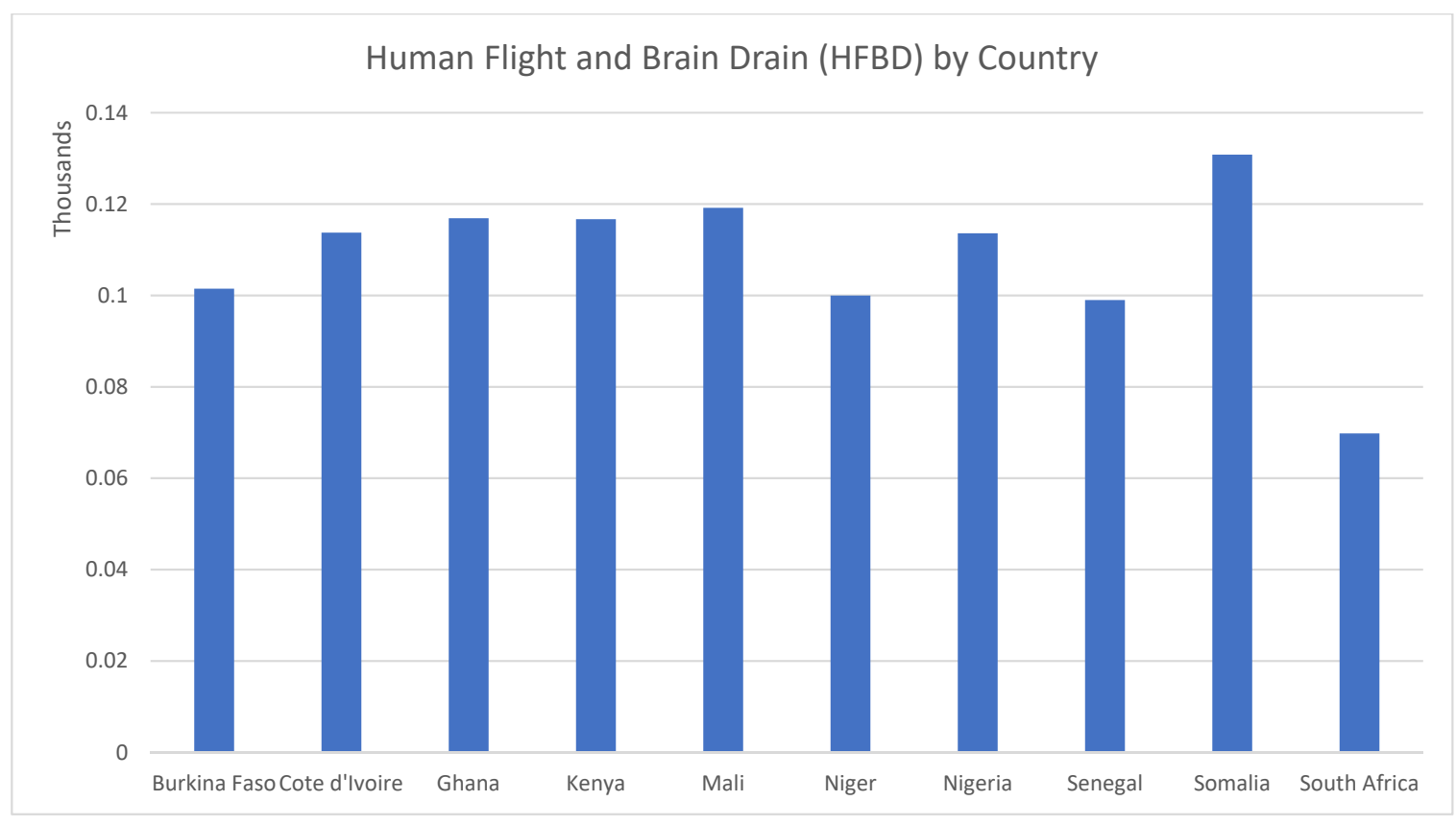

Figure 3. Trend of human flight and brain drain in selected Sub-Saharan African countries. 
Table 1 shows the record of skilled migrants from the African continent from 1999 to 2020. From the table, the trend of skilled migrants continued to increase from 738.6 in 1990-1999 to 1781.6 in 2000-2009, 2843.3 in 2010-2018, and 3676.1 in 2019-2020. Regarding the Sub-Saharan African countries that are focal for our research, about 52.2\% of highly skilled migrants left their countries to look for greener pastures from 1990 to 1999. From 2000 to 2009, approximately 57.4\% migrated to a different part of the globe, particularly Europe, while in 2010-2018 and 2019-2020, the values are approximately 60.4\% and $62.8 \%$ respectively.

Table 1. Record of energetic skilled migrants from Africa, 1990-2020.

\begin{tabular}{ccccc}
\hline (In Thousands) & $\mathbf{1 9 9 0 - 1 9 9 9}$ & $\mathbf{2 0 0 0 - 2 0 0 9}$ & $\mathbf{2 0 1 0 - 2 0 1 8}$ & $\mathbf{2 0 1 9 - 2 0 2 0}$ \\
\hline Northern Africa & $\mathbf{2 6 4 . 4}$ & 643.8 & 1072.4 & 1382.1 \\
\hline & $35.8 \%$ & $41.4 \%$ & $36.9 \%$ & $37.4 \%$ \\
\hline $\begin{array}{c}\text { Sub-Saharan } \\
\text { Africa }\end{array}$ & 486.3 & 895.8 & 1879.9 & 2300.3 \\
\hline Western Africa & $52.2 \%$ & $57.4 \%$ & $60.4 \%$ & $62.8 \%$ \\
\hline Southern Africa & 154.7 & 298.4 & 706.3 & 825.7 \\
\hline & $20.8 \%$ & $19.4 \%$ & $21.8 \%$ & $23.8 \%$ \\
\hline Eastern Africa & 80.2 & 150.7 & 297.8 & 352.9 \\
\hline & $11.9 \%$ & $9.6 \%$ & $10.4 \%$ & $10.8 \%$ \\
\hline Middle Africa & 300.5 & 326.9 & 604.1 & 756.5 \\
\hline & $30.3 \%$ & $20.2 \%$ & $20.7 \%$ & $22.1 \%$ \\
\hline
\end{tabular}

Source: Calculated by the authors using DM06 and DIOC. Docquier and Marfouk are represented by the letters DMO6. The datasets of 1990, 2006, 2009, 2019, 2020 were used, and DIOC stands for Database on Immigrants in OECD Countries.

\section{Literature Review}

Human capital flight and brain drain continue to be a serious challenge in developing countries, notably in Sub-Saharan Africa. Furthermore, underdeveloped countries already have low human development indices, and further human resource movement will exacerbate the country's plight [31]. It is true that the economies of Sub-Saharan African countries are in shambles, and the trend of young people fleeing goes beyond this factor [32-35]. For example, the number of people planning to leave or move is linked to a number of indices. Poor health in Sub-Saharan African countries, high unemployment up to $18.8 \%$ in the third quarter of 2017, and rising poverty rates with up to $80 \%$ below the poverty line, as well as insecurity [36-39], are just a few of these reasons. For example, approximately 27,000 African professionals fled the continent for western countries between 1960 and 1965, creating a pattern of African brain drain. The problem began in the mid-1980s when the bulk of Africans who traveled overseas to complete their studies did not return to their home nations [40]. Thus, more than $44 \%$ of African residents who completed their education abroad between 1986 and 1996, particularly doctorate programs, refused to return home [3]. Similarly, between 1999 and 2001, regarding PhD students, Africans accounted for 1515 out of 34,649 non-American nationals [41]. These conclusions were further supported by [3]. Thus, the rates of trained, non-returning African personnel in Europe, North America, and the world overall have continued to increase over the years into the most recent decade.

The majority of the diaspora's contribution to development in terms of remittances in African countries, particularly Sub-Saharan African (SSA) countries, is mostly to support their families $[42,43]$. This is in stark contrast with the stream of remittances witnessed in other emerging economies, where diaspora participation is crucial to their nations economic progress [44-46]. By implication, diaspora participation continues to be a critical 
nexus for attracting the human, social, and financial capital required for socioeconomic growth. Hence, a practical development framework is required since remittances are an important source of foreign currency in Sub-Saharan Africa. Global remittance flows are expected to fall as a result of COVID-19, with Sub-Saharan Africa experiencing a greater decline than the global average [47]. For example, COVID-19 drives two concurrent processes that influence remittance flows: The decreased ability to transmit and collect remittance flows through official channels and the decreased demand for migrant labor and lower earnings, both as a result of domestic lockdowns and economic declines [30, 31]. Equally, reduced foreign remittances may dramatically lower household spending and increase poverty levels in countries that are particularly reliant on them, further exacerbating the local economic shock felt by developing nations and possibly affecting the progress toward meeting SDGs target by 2030 [48]. Worthy of note is that approximately $40 \%$ of the African population is estimated to be living in poverty [14]. Therefore, ignoring the consequences of human capital flight and brain drain may lead to a failure to consider its effects on economic policies.

\section{Theoretical Framework}

The push-pull theory is the most-utilized theory to understand the issue of brain drain. The explanation underlying the flow of competent persons from poor countries to developed countries is owing to endemic poverty and underdevelopment [49]. Push factors are circumstances within the domestic country that cause people to leave [50]. These include economic issues such as poverty, income inequality, and other factors such as low educational standards, and political instability such as corruption and political violence, among others. The fact is that these assertions are the primary reasons for migratory push forces. Other reasons for human capital flight under push factors include the lack of a conducive learning environment and insufficient facilities for professionals to practice [51] In contrast, the elements that offer a safe and stable work environment, a high standard of living, opportunities for career progress, higher incomes, employment flexibility, and a predictable workload are known as pull factors [52]. Labor shortages in Europe and North America function as an extra incentive or "pull" element for migration [41].

Contrastingly, there are three other migration factors that push or pull migrants back to their native country: Economic, psychological, and situational. The lack of employment prospects and the inability to use skills acquired in one's home country are two economic factors. Family reunification and altruism are the psychological push factors highlighted by [53]. Finally, from the standpoint of the host country, situational push factors are recognized. Discrimination in the host country, inability to adapt in the host country, and problems associated with being members of a minority group are among them. As a result, we can observe that the proposals in [53] are diametrically opposed to those in [54]. Pull factors such as untapped investment opportunities and increased demand (i.e., economical pull factors), seeking identity, old age (i.e., psychological pull factors), and political development (i.e., situational pull factors) also influence migrants' decisions in host countries [53].

From the viewpoints of remittance, the common theories used were altruism and the social network theory. According to altruism theory, one of the motives behind individuals immigrating is the opportunity for them to maximize their prospects. With the exclusion of individuals who are forced to migrate due to conflict, some economists have traditionally seen immigration as predominantly driven by individual choices [55]. Members of the New Economics of Labor Migration (NELM), a Neo-Classical economics group cited in [56-58], pointed out that the family unit is the primary driver of migration. The Members of NELM further believe that past research has frequently overlooked the impact of migration on the country of origin. 
On the other hand, the social network theory works to investigate the connections between individuals, groups, and organizations. Thus, there are four basic assumptions that flow from the theory. To begin with, the knowledge structures and processes are built on the foundation of interpersonal relationships. Second, relationships are structured in a way that can be quantified. Third, structured interactions, like cognitive qualities, are behavioral. Fourth, organized interactions give rise to cognitive and behavioral traits. This theory was based on a number of techniques and can be understood using matrix and algebra ideas. These connections are thought to be measurable in terms of clusters and point interactions. Links and their connections are frequently referred to as nodes, as supported by $[57,58]$.

There is an absence of push-pull, altruism, and social network theories in various works in the literature, and particularly the complimentary application of the theories, and migrant remittance inflows may have a significant impact on sustainable growth as well as the livelihood of their families in their countries of origin. Despite the differences in these theories, these theories are highly linked with respect to our topic under investigation, more so than the acknowledgement given in previous studies in the literature. Nevertheless, the techniques we used in this study are capable of capturing the deviations that are significant to the successive techniques of investigation, used to uncover the developments of the global standpoint of deliberation to the specific albeit new fact regarding the discussion of how growth performance has been affected by remittance inflows, human capital flight and brain drain, poverty, corruption, income inequality, and total trade in select SubSaharan African countries. Therefore, problems associated with remittance inflows, human capital flight, and brain drain should be addressed with immediate effect. As a result, the pull-push theory serves as the basis for this research.

\section{Materials and Methods}

The objective of this study is to investigate the impact of remittances, human capital flight, and brain drain on the sustainable economic growth (i.e., SDGs target) in SSA by the year 2030 by means of yearly data from 2006 to 2020, employing the panel of ARDL ECM techniques. The ARDL and ECM are incorporated to determine both the short- and long-term associations among the variables. In addition, the technique validates I(0), I(I), or the combination of the two orders, but does not accept the I(2) order of integration [59]. Thus, the ARDL technique has an advantage over the OLS method, pooled OLS, etc., because using the same result can be ascertained using one technique. The fact is that theoretical and empirical economic models are designed to solve different problems, but the best method to uncover the existing standpoints in an acceptable and empirical method is using a theory or a model to predict a hypothesis or question and comparing the results with the existing evidence(s) [60].

The panel ARDL approach is credited to [61] as modified in [62], and the technique's ability to accept varying lags in multiple variables makes it predominantly interesting, robust, and adaptable. The fact is that the technique produces consistent estimates and correct t-statistics $[63,64]$. In fact, residual correlations are minimized as a result of proper lag selection, and therefore the endogeneity problem is reduced [65]. The ECM is employed to link the short-term divergence with long-term convergence $[60,65]$. Therefore, ARDL is utilized since our model meets the necessary conditions. Therefore, this section presents the map of SSA as the study area in Figure 4, and the data sources, description, and model specifications for the investigation follow.

As shown in Figure 4, the map of Africa as the study area has 54 economies. However, only ten selected SSA countries are included, namely Senegal, Mali, Niger, Ghana, Nigeria, Cote D'ivoire, Burkina Faso, Somalia, and South Africa. We selected these countries based on growing challenges such as inadequate opportunities in the labor market, decent work and wages for all, inequalities, increases in population growth, and extreme poverty in terms of global indexes, as well as on their connection and exposure to human capital flight and brain drain or the level of remittance inflow received, among other reasons. 


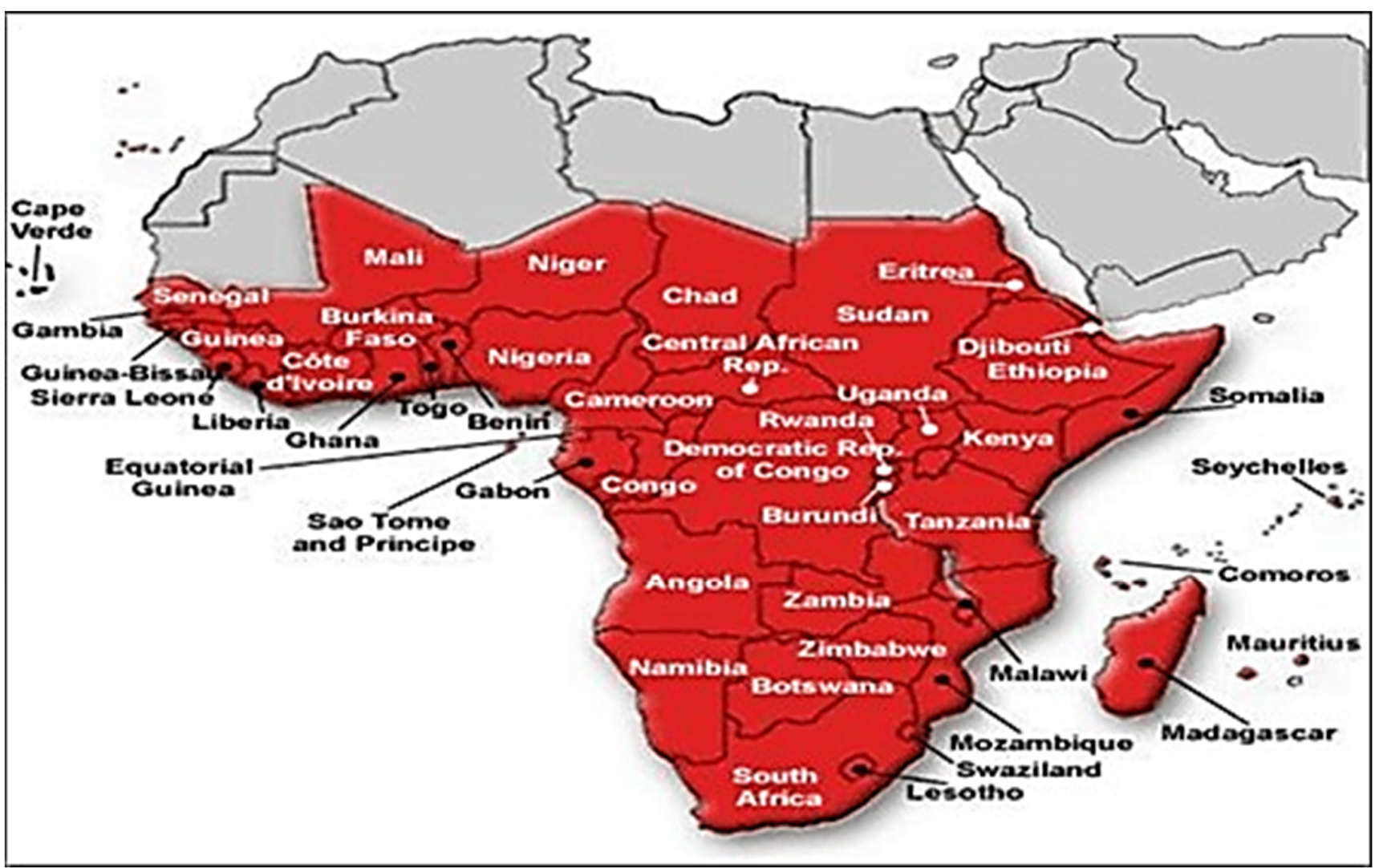

Figure 4. Map of Sub-Saharan Africa as the area of a study showing 54 countries. (Source: http:// greatlakesvoice.com/one-in-every-nine-children-in-sub-saharan-africa-dies-before-age-of-5-study/ (accessed on 8 December 2021).

\subsection{Data Description}

The data from this study were sourced from the fragile states index published by the United States policy institute, The Fund for Peace (FFP), and the American magazine, Foreign Policy (AMFP), International Monetary Fund (IMF), and world development indicators (WDI) databases. See Table 2.

Table 2. Variable description.

Is measured by the annual rate of the real Gross Domestic Product (GDP). It is the annual percentage rate of GDP at market prices in the individual countries' local currencies. However, the total is calculated in US dollars. It is calculated without taking into account asset depreciation or natural resource depletion. This variable was sourced from the World Bank's Development Indicators 
Table 2. Cont.

Variables

Human capital Flight and Brain Drain (lnHFBD)
Measurement and Description

This index looks at the economic impact of human displacement (whether for economic or political reasons) and the implications for a country's development. On the one hand, voluntary emigration of the middle class, particularly economically productive segments of the population, such as entrepreneurs, or skilled workers, such as physicians, may occur as a result of economic decline in their home country and the pursuit of better opportunities elsewhere. The indicator is measured as whether conditions are improving or worsening. The data were sourced from database of the fragile states index published by the United States policy institute, The Fund for Peace (FFP), and the American magazine, Foreign Policy (AMFP) 2020

The corruption perception index (CPI) is a tool for assessing the level of corruption in different countries. The CPI is a 0 to 100 scale, with 0 signifying extreme corruption and 100 representing no Corruption (lnCUPT) corruption. A rise in the CPI indicates a decrease in corruption. The

Gini coefficient and the CPI are expected to have a negative connection. The Transparency International database was used to compile the CPI.

The Gini index is the most-used measure of income inequality. The Gini index ranges from 0 to 1 , with 0 indicating complete income equality and 1 indicating absolute disparity. The data were sourced from Gini index (World Bank estimate 2020.

Income inequality (lnINEQ)

Total trade is the sum of goods and services exports and imports expressed as a percentage of GDP, which is based on data from the

World Bank's national accounts 2020 and the OECD's national accounts files.

This comprises personal remittances, personal payments, and employee remuneration. All current monetary or in-kind transfers made or received by resident households to or from nonresident households are classified as personal transfers. As a result, personal transfers encompass all current transfers between residents and nonresidents. Employee compensation refers to the earnings of border, seasonal, and other short-term workers engaged in a

non-resident economy, as well as residents employed by non-resident organizations. Personal transfers and employee compensation are the total of two items defined in the sixth edition of the IMF's Balance of Payments Manual. The figures are in current US dollars, which was sourced from WDI 2020.

This includes the ratio of people living in poverty at national poverty levels (percent of population). The data were sourced from World Bank data, world development indicator 2020.

\subsection{Specification of the Model}

Various functional forms describe the research model relationship. Therefore, the study varies with the related models reviewed in the study, as it takes into account remittance inflows, human capital flight and brain drain, corruption, and income inequality variables, as specified below.

$$
\mathrm{RGDP}=\mathrm{f}(\mathrm{HFBD}, \mathrm{REMT}, \mathrm{TTRD}, \mathrm{CUPT}, \mathrm{PVTY}, \mathrm{INEQ})
$$

The linear relationship is as follows:

$$
\operatorname{RGDP}_{\mathrm{i}, \mathrm{t}}=\theta_{0}+\theta_{1} \mathrm{HFBD}_{\mathrm{i}, \mathrm{t}}+\theta_{2} \mathrm{CUPT}_{\mathrm{i}, \mathrm{t}}+\theta_{3} \mathrm{INEQ}_{\mathrm{i}, \mathrm{t}}+\theta_{4} \mathrm{REMT}_{\mathrm{i.t}}+\theta_{5} \mathrm{PVTY}_{\mathrm{i}, \mathrm{t}}+\theta_{6} \mathrm{TTRD}_{\mathrm{i}, \mathrm{t}}+\varepsilon_{\mathrm{i}, \mathrm{t}}
$$


where: $\mathrm{i}=10$ selected Sub-Saharan African countries.

$\mathrm{t}=$ time $(2006,2007,2008,2009 \ldots 2020)$.

$\mathrm{RGDP}_{\mathrm{i}, \mathrm{t}}=$ Gross domestic product per capita (annual\% in current US dollars).

$\mathrm{HFBD}_{\mathrm{i}, \mathrm{t}}=$ Human flight and brain drain (the indicator is measured as whether conditions are improving or worsening).

$\mathrm{CUPT}_{\mathrm{i}, \mathrm{t}}=$ Corruption: The corruption perception index (CPI) is measured on a 0-100 scale. $\mathrm{INEQ}_{\mathrm{i}, \mathrm{t}}=$ Income inequality (The Gini index is measured from 0-1).

$\mathrm{REMT}_{\text {i.t }}=$ Remittance inflow received (at current US dollars).

PVTY $_{i, t, t}=$ Poverty: This includes the ratio of people living in poverty at national poverty levels (measured as a \% of the total population).

TTRD $_{\mathrm{i}, \mathrm{t}}=$ Total trade: Total trade is the sum of goods and services exported and imported, expressed as a \% of GDP.

$\mathrm{U}_{\mathrm{i}, \mathrm{t}}=$ Stochastic Error Term.

$\theta_{0}=$ the intercept of the model.

$\theta_{1}, \theta_{2}, \theta_{3}, \theta_{4}, \theta_{5}$ and $\theta_{6}=$ Coefficients of the independent variables.

The panel ARDL model is specified as follows [66]:

$$
\theta_{i, t}=\beta_{i, t}+\alpha_{0 i, t} X_{i, t}+\varepsilon_{i, t}
$$

where $\theta$ is the dependent variable, $X$ is the independent variable, $\beta$ and $\alpha$ are the coefficients, and $i$ and $t$ are indices for individuals and time. The error $\varepsilon_{i t}$ is very important in this analysis [67].

$$
\theta_{\text {it }}=\beta_{i t}+\sum_{i=1}^{k} \delta_{i z} \theta_{z t-1}+\sum_{i=0}^{\mathrm{q}} \alpha_{i, t} x_{z t-1}+\varepsilon_{i, t}
$$

$$
\begin{aligned}
& \Delta \mathrm{RGDP}_{\mathrm{it}}=\beta_{\mathrm{i}}+\sum_{\mathrm{i}=1}^{\mathrm{k}} \delta \mathrm{iz} \Delta \operatorname{lnHFBDz}_{\mathrm{t}-1}+\sum_{\mathrm{i}=0}^{\mathrm{k}} \beta \mathrm{iz}, \Delta \ln \mathrm{CUPTz}_{\mathrm{t}-1}+\sum_{\mathrm{i}=0}^{\mathrm{k}} \text { Xiz, } \Delta \ln \text { INEQTz }_{\mathrm{t}-1} \\
& +\sum_{\mathrm{i}=0}^{\mathrm{k}} \beta \mathrm{iz}, \Delta \ln \text { PVTY }_{\mathrm{t}-1}+\sum_{\mathrm{i}=0}^{\mathrm{k}} \beta \mathrm{iz}, \Delta \ln \mathrm{REMTz}_{\mathrm{t}-1}+\sum_{\mathrm{i}=0}^{\mathrm{k}} \beta \mathrm{iz}, \Delta \ln \operatorname{TTRDz}_{\mathrm{t}-1}+\varepsilon_{\mathrm{i}, \mathrm{t}} .
\end{aligned}
$$

where $\mathrm{i}$ is $1, \mathrm{n}$ is the national index, $\mathrm{t}$ is $1, \ldots$, and $\mathrm{T}$ is the time index and is the random disturbance term given $\mathrm{N}=\mathrm{n} \mathrm{T}$ data points. Furthermore, $\mathrm{t}$ denotes the passage of time, $\mathrm{I}$ is the country under investigation as well as the first variation component, and $\mathrm{k}$ denotes the optimal lag length.

\section{Results}

To fully comprehend the dynamics of overall lnRGDP in the economies of the selected Sub-Saharan African countries, descriptive statistics are presented in Table 3. Based on the historical trend of lnRGDP in the selected Sub-Saharan African economies, the average growth rate of $\ln R G D P$ is around $6.34 \%$, with a maximum of $8.21 \%$ and a minimum of $8.20 \%$. The highest growth could arguably be due to the influence of trade expansion across Sub-Saharan Africa, where the annual rate of the ade volume grew by 5.90. Worthy of note is that $5.90 \%$ is much greater than the global average of $3.80 \%$. Our trade figures in this study justify this, for example with the standard deviation values of $15.53 \%$ and $21.37 \%$. Accordingly, the indicators are ascertained accompanied by the average values of kurtosis of $16.39 \%$ and $5.73 \%$, with significant dispersions, establishing the RGDP improvement to be platykurtic. The lnCUP annual variation rate ranged from $63.40 \%$ to $31.50 \%$, while lnHFBD was $9.80 \%$ to $4.00 \%$. Accordingly, lnINEQ presented a maximum of $9.50 \%$ with a minimum of $5.97 \%$. Thus, lnPVTY has a maximum of $62.10 \%$ with a minimum of $23.40 \%$. Therefore, $\operatorname{lnREMT}$ displays $23.91 \%$ and $18.03 \%$ as a maximum and minimum, respectively. This has coincided with the World Bank's report that remittances in developing countries are set to increase. Accordingly, lnHFBD has a maximum of $9.80 \%$ and a minimum of 4.0 percent. 
Table 3. Panel descriptive statistics.

\begin{tabular}{cccccccc}
\hline Variables & $\operatorname{lnRGDP}$ & $\operatorname{lnCUPT}$ & $\operatorname{lnHFBD}$ & $\operatorname{lnINEQ}$ & $\operatorname{lnPVTY}$ & $\operatorname{lnREMT}$ & $\operatorname{lnTTRD}$ \\
\hline Mean & 6.346799 & 41.63267 & 7.207094 & 7.794118 & 43.75600 & 2.940000 & 59.47326 \\
Median & 179146.5 & 38.90000 & 7.437641 & 7.900000 & 43.80000 & 8.920000 & 58.08939 \\
Maximum & 8.210356 & 63.40000 & 9.800000 & 9.500000 & 62.10000 & 23.91420 & 4.897762 \\
Minimum & 8.200000 & 31.50000 & 4.000000 & 5.970653 & 23.40000 & 18.03496 & 3.031221 \\
Std. Dev. & 15.52968 & 9.010520 & 1.221451 & 0.815540 & 9.093463 & 5.870000 & 21.37446 \\
Skewness & 3.798950 & 1.681322 & -0.832853 & 0.013111 & -0.378437 & 2.622814 & 1.418660 \\
Kurtosis & 16.39509 & 4.568027 & 3.499982 & 2.315139 & 3.980696 & 8.233647 & 5.736699 \\
Observation & 150 & 150 & 150 & 150 & 150 & 150 & 150 \\
\hline
\end{tabular}

As shown in Table 4, which shows Panel Levin, Lin, and Chu unit root test results, with the exception of $\operatorname{lnHFBD}$, InCUPT, and lnPVTY, whose probability values are less than the $5 \%$ level of significance, the null hypothesis of the presence of the unit root has been rejected at this level. Meanwhile, the null hypothesis of the presence of the unit root has not been rejected at this level with respect to $\ln R$ GDP, $\operatorname{lnREMT}$, InINEQ, and $\operatorname{lnTTRD}$ because they are greater than the $5 \%$ significance level, implying that they are I(I) variables [68]. The null hypothesis confirming the presence of the unit root test is, however, rejected, after taking the first difference of all the variables. The result demonstrates that panel ARDL analysis can be used to determine the long-term relationship between the variables of interest.

Table 4. Panel Levin, Lin, and Chu unit root test results.

\begin{tabular}{|c|c|c|c|c|}
\hline Variables & Level & Probability & 1st First Diff. & Probability \\
\hline $\ln R G D P$ & -0.07722 & 0.4692 & -6.04066 & $0.0000^{* * *}$ \\
\hline $\ln H F B D$ & -2.26048 & $0.0119 * *$ & -2.71470 & $0.0033^{* * *}$ \\
\hline $\operatorname{lnCUPT}$ & -2.18459 & $0.0145^{* *}$ & -7.38175 & $0.0000^{* * *}$ \\
\hline $\operatorname{lnINEQ}$ & 0.51150 & 0.6955 & -2.87299 & $0.0020^{* * *}$ \\
\hline $\operatorname{lnPVTY}$ & -4.10450 & $0.0000^{* * *}$ & -17.1677 & $0.0000^{* * *}$ \\
\hline $\operatorname{lnREMT}$ & -0.87312 & 0.1913 & -5.25573 & $0.0000^{* * *}$ \\
\hline lnTTRD & -1.19396 & 0.1162 & -4.85916 & $0.0000^{* * *}$ \\
\hline
\end{tabular}

The panel Im, Pesaran, and Shin W-stat unit root test results are shown in Table 5. With the exclusion of $\operatorname{lnCUPT}$ and $\operatorname{lnPVTY}$, whose probability values are less than the $5 \%$ level of significance, the results imply that the variables are integrated at an order of zero (i.e., I (0)). The null hypothesis of the presence of the unit root is rejected since the associated probability is less than the $5 \%$ significance level [61]. The null hypothesis confirming the presence of the unit root test is, however, rejected after taking the first difference of the variables. Therefore, this also confirms the validity of using panel ARDL analysis to determine the long-term relationship between the variables under investigation.

Table 5. Panel Im, Pesaran, and Shin W-stat unit root test results.

\begin{tabular}{ccccc}
\hline Variables & At level $\boldsymbol{t}$-Stats & Probability & At First Diff. & Probability \\
\hline $\ln R G D P$ & 1.63636 & 0.9491 & -3.28563 & $0.0005^{* * *}$ \\
\hline $\ln$ HFBD & 0.10213 & 0.5407 & -2.08480 & $0.0185^{* *}$ \\
\hline $\ln$ CUPT & -2.13989 & $0.0162^{* *}$ & -7.70647 & $0.0000^{* * *}$ \\
\hline $\ln$ INEQ & 1.00848 & 0.8434 & -2.35366 & $0.0093^{* *}$ \\
\hline $\ln$ PVTY & -3.01506 & $0.0013^{* * *}$ & -10.6198 & $0.0000^{* * *}$ \\
\hline $\ln$ REMT & 0.72945 & 0.7671 & -4.22861 & $0.0000^{* * *}$ \\
\hline $\ln$ TTRD & -1.02571 & 0.1525 & -3.71927 & $0.0001^{* * *}$ \\
\hline$* * * * *$, indicates significance at $1 \%, 5 \%$ level respectively. & &
\end{tabular}


As exhibited in Table 6, the coefficients of the short-term effects of $\operatorname{lnCUPT}$, lnHFBD, lnINEQ, InPVTY, InREMT, and lnTTRD demonstrated significant statistical values, which are influenced by their lags. In the short term, the relationship between $\mathrm{D}(\operatorname{lnHFBD})$, $\mathrm{D}(\operatorname{lnCUPT}), \mathrm{D}(\ln P V T Y)$, and $\mathrm{D}(\operatorname{lnINEQ})$ have an endogenous negative influence on RGDP of the selected SSA nations in both the first and second lags. Similarly, D(lnREMT) and $\mathrm{D}(\operatorname{lnTTRD})$ have a significant positive influence on RGDP at the $5 \%$ level, which is induced by their lags. The implication is that increases in remittance inflows, as well as the trade volume, have an influence on the sustainable economic growth of the selected SSA countries, given the established significance of the real GDP in the first lag. Worthy of note is that we are confident this result answered our research question and meets our research objective, given there is evidence that our variables of interest have an impact on sustainable economic growth in SSA.

Table 6. Short-term panel ARDL estimate coefficients.

\begin{tabular}{|c|c|c|c|}
\hline Variables & Coefficients & $t$-Statistics & Probability \\
\hline $\operatorname{Dln}(\operatorname{RGDP}(-1))$ & 0.078330 & 0.203250 & 0.8398 \\
\hline Dln(HFBD) & -1.869593 & -2.277048 & $0.0255^{* *}$ \\
\hline $\operatorname{Dln}(\operatorname{HFBD}(-1))$ & -0.248478 & -0.174154 & 0.8622 \\
\hline $\mathrm{D} \ln (\mathrm{CUPT})$ & -6.239056 & -3.311574 & $0.0194^{* *}$ \\
\hline Dln(CUPT(-1)) & -2.201624 & 0.720485 & 0.4742 \\
\hline Dln(INEQ) & -12.79612 & -2.404805 & 0.0368 ** \\
\hline $\operatorname{Dln}(\operatorname{INEQ}(-1))$ & -31.05166 & -1.645592 & 0.1065 \\
\hline Dln(PVTY) & -6374.370 & -3.687161 & $0.0494^{* *}$ \\
\hline Dln(PVTY(-1)) & -4765.844 & -1.168573 & 0.2474 \\
\hline Dln(REMT) & 0.090710 & -2.803380 & $0.0424^{* *}$ \\
\hline $\operatorname{Dln}(\operatorname{REMT}(-1))$ & 0.085196 & 0.451296 & 0.6530 \\
\hline Dln(TTRD) & 0.095026 & -2.165080 & $0.0286^{* *}$ \\
\hline $\operatorname{Dln}(\operatorname{TTRD}(-1))$ & 0.063006 & 0.150186 & 0.8810 \\
\hline $\mathrm{ECT}_{\mathrm{t}-1}$ & -0.266282 & -2.602419 & $0.0123^{* *}$ \\
\hline
\end{tabular}

$\overline{* *}$, indicates significance at $5 \%$.

Accordingly, the EC term produced a satisfactory sign with an approximate value of -0.266 and the associated probability (i.e., 0.0123 ). As a result, a value of 0.266 indicates a $26.6 \%$ speed adjustment to reach equilibrium in the designated time. This implies that the system would be able to return to the path of equilibrium after several shocks. Therefore, for the selected SSA economies' real gross domestic product to improve, remittances must account for at least a 26.6 percent share of the yearly impact inflow to overcome the persistent human capital flight challenges in the region. This is comparable to the findings of a previous study [69]. As a result, a return to convergence will take four years on average, although authorities (i.e., government institutions and departments of the selected SSA countries, government agencies, and private organizations) may implement active policies and programs that can offer opportunities for decent work, wages, and favorable labor market participation for all who wish to seek employment, as well as providing traceable channels for remittance inflows into their countries to ensure the remittance system is easy to access as well as policies that will prevent human capital flight and brain drain. Our model results, however, make sense in light of the recent migrant outflow from SSA, as evidenced by the 2019 World Bank report on SSA.

As shown in Table 7, human capital flight and brain drain (HFBD), corruption (CUPT), income inequality (INEQ), and poverty (PVTY) all have negative and statistically significant effects on the economic growth performance, and the result is confirmed by the long-term coefficients and their associated probability. However, while the remittance inflow has 
a direct impact on sustainable growth, it is negligible to determine an exact, real, macro impact because most of the remittance inflows enter the country through informal means of payments and most of the beneficiary households spend their remittance on consumption rather than investing in productive sectors of the economy. This is supported by the findings of [70]. Finally, trade (TTRD) has a statistically significant positive impact on the RGDP of the Sub-Saharan African countries. This means that a $1 \%$ rise in the trade volume will result in a $2.35 \%$ increase in the real GDP. As a result, an increase in remittance inflows as well as the trade volume has an impact on the selected SSA countries' sustainable economic growth. It is also worth noting that we are confident that this result answered our research question and meets our research objective of finding evidence that our variables of interest have an impact on SSA's sustainable economic growth.

Table 7. Long-term panel ARDL estimate coefficients.

\begin{tabular}{c|c|c|c}
\hline \multicolumn{4}{c}{ Dependent Variable: DLOG(RGDP) } \\
\hline \multicolumn{4}{c}{ Maximum dependent/ Dynamic regressors lags Selected: 2} \\
\hline \multicolumn{5}{c}{ Long Run Equation/coefficients } \\
\hline Variables & Coefficients & $t$-statistics & Probability \\
\hline $\ln ($ HFBD) & -0.977514 & 6.116526 & $0.0000^{* * *}$ \\
\hline $\ln ($ CUPT) & -25.05624 & -4.346021 & $0.0001^{* * *}$ \\
\hline $\ln ($ INEQ) & -14.15963 & -62.13655 & $0.0000^{* * *}$ \\
\hline $\ln$ (PVTY) & -49732.77 & -8.375081 & $0.0000^{* * *}$ \\
\hline $\ln ($ REMT) & 0.013440 & -1.283581 & 0.2031 \\
\hline $\ln ($ TTRD) & 2.359428 & 87.73959 & $0.0000^{* * *}$ \\
\hline${ }_{* * *}^{*}$ indicates significance at 1\% level.
\end{tabular}

As exhibited in Table 8, the computed t-statistics, F-statistics, and Chi-square of the Wald test are 221.66, 49,134.24, and 49,134.24, respectively, and their corresponding probability values of 0.0000 are highly significant at the $1 \%$ level. Overall, the selected variables fit because the related parameters with respect to these variables of the model are not zero. The generalization of this study is trustworthy, with the cumulative impact revealed by the Wald coefficient diagnostics. As a result, an increase in remittance inflows, as well as the trade volume, has an impact on the selected SSA countries' sustainable economic growth, as well as decreases in human capital flight and brain drain, poverty, corruption, and income inequality. It is also worth noting that we are confident that this result answered our research question and meets our research objective of finding evidence that our variables of interest have an impact on SSA's sustainable economic growth [71].

Table 8. Panel Wald coefficient diagnostic test.

\begin{tabular}{ccc}
\hline Test Statistic & Values & Prob \\
\hline t-statistic & 221.6624 & $0.0000^{* * *}$ \\
\hline F-statistic & 49134.24 & $0.0000^{* * *}$ \\
\hline Chi-square & $49,134.24$ \\
\hline Null Hypothesis: C $(1)+\mathrm{C}(2)+\mathrm{C}(3)+\mathrm{c}(4)+\mathrm{c}(5)+\mathrm{c}(6)+\mathrm{c}(7)=0$ \\
\hline Normalized Restriction (=0) & Value & Std. Err. \\
\hline
\end{tabular}

Restrictions are linear in coefficients. ${ }^{* * *}$ indicates $1 \%$ significance.

Similarly, the model's distribution is normal, as illustrated in Table 9, considering the constant and the mean are around zero; this signifies the residuals are normally distributed, as indicated by the Jarque-Bera statistics (5.091902) and probability value (approximately 0.0786 , which is greater than the $5 \%$ level of significance) $[71,72]$. 
Table 9. Histogram normality residual diagnostic checks.

\begin{tabular}{cc}
\hline Jarque-B Stat. & Probability \\
\hline 5.091902 & 0.078398 \\
\hline
\end{tabular}

\section{Discussion}

Remittances, human capital flight, and brain drain continue to be critical issues for discussion among governments and policy makers to solve macroeconomic dynamics, particularly in SSA. Globally, these indicators offer cost and benefit trade-offs from the view of achieving SDGs-8 objectives and the wellbeing viewpoint of recipient communities, as identified in the literature. For example, in recent years, the importance of remittances to many developing economies, particularly African economies, cannot be overstated [2]. Furthermore, the rate at which human capital is fleeing SSA is concerning, and it might be a useful measure of macroeconomic policy consequences, particularly in terms of providing chances in the domestic labor market, jobs, and decent work for all in SSA economies. As a result, neglecting the repercussions of human capital flight and brain drain may result in failure to examine the economic policy implications. For example, the Corona virus pandemic (i.e., COVID-19) is still restraining travelers as well as challenging both the economic and welfare status of recipient communities in SSA [30,31,73]. Thus, this is a matter of great concern in achieving sustainable economic growth (i.e., SDGs-8) in SSA as global remittance flows are expected to fall as a result of COVID-19, with Sub-Saharan Africa experiencing a greater decline than the global average [47]. For example, COVID-19 drives two concurrent processes that influence remittance flows: The decreased ability to transmit and collect remittance flows through formal channels due to lockdowns and economic declines, and the decreased demand for migrant labor and lower earnings [30,31].

Next, we discuss the empirical techniques. The short-term coefficients revealed that lnCUPT, lnHFBD, lnINEQ, lnPVTY, lnREMT, and lnTTRD, as shown in Table 4, indicate significant statistical values given their lags. In the short term, the connections between $\mathrm{D}(\operatorname{lnHFBD}), \mathrm{D}(\operatorname{lnCUPT}), \mathrm{D}(\ln P V T Y)$, and $\mathrm{D}(\operatorname{lnINEQ})$ have an endogenous negative influence on the RGDP of the selected SSA economies. Similarly, D(lnREMT) and D(lnTTRD) have a positive influence on the RGDP at the $5 \%$ level. There is enough evidence to reveal the existence of a long-term impact of the variables of interest on economic sustainability in SSA. Thus, an increase in remittance inflows as well as the trade volume has positive economic benefits, particularly in terms of job creation and decent work for all by 2030, and this conforms with the findings of previous research [44-46]. Similarly, the EC term exhibited a satisfactory sign with a value of -0.266 and an associated probability of 0.0123 . As a result, the value of 0.266 represents a $26.6 \%$ speed adjustment required to reach symmetric convergence in the designated time. This implies the system would be able to return to a path of symmetric convergence after several deviations to the system. Therefore, for the selected SSA economies to achieve SDGs-8, remittances must account for at least a 26.6 percent share of the yearly inflow to overcome the persistent human capital flight, corruption, poverty, and inequality, among the other negative effects challenging growth in the SSA region [21-23]. This is supported by the findings of [65]. Finally, trade (TTRD) has a statistical and significant positive impact on the RGDP of Sub-Saharan African countries. This means that a rise in the trade volume will help in achieving sustainable economic growth, particularly regarding opportunities in the labor markets that provide decent work and wages for all in SSA by the year 2030. The findings of this research are trustworthy and in line with the 2019 World Bank report on SSA SDGs goals of 2030 regarding remittances and human capital flight targets. Thus, the majority of prior studies on remittances, human flight and brain drain, and economic growth have not considered this contribution. Next, the overall finding from the Wald coefficient restriction revealed that the related parameters with respect to these variables of the model are non-zero, as clearly shown in Table 7 [71]. This finding confirms that our variables of interest in the model should be retained for the investigation. Finally, the model's distribution is normal, as illustrated in Table 8, 
considering the constant and the mean are around zero, which signifies the residuals are normally distributed, as indicated by the Jarque-Bera statistics (5.091902) and probability value (approximately 0.0786 , which is greater than the $5 \%$ level of significance) [72]. On a final note, the overall impact of our variables in both the short-term and long-term estimates are supported by the United Nations SDGs' target that demands developing economies meet on, an annual basis, at least 7 percent growth in order to bridge the gap (i.e., catch up in the development process) between developing and developed countries [74]. Given the findings from this investigation, we can say that we have evidence to state that achieving the target of SDGs by the year 2030 for decent work and jobs for all, with a reduction in human capital flight and brain drain, corruption, inequality, and poverty can be achieved. These findings are hardly investigated by the extant studies in the literature.

\section{Conclusions}

Using annual data from the period of 2006 to 2020 in this investigation, a panel ARDL was employed to determine the short- and long-term impact of remittances, human capital flight, and brain drain on the sustainable economic performance of certain SSA African countries. While remittances and human capital flight can be an important indicator for accomplishing SDGs by the year 2030, they are seldom considered in the extant literature. The fact is that the majority of prior studies on remittances, human flight and brain drain, and economic growth were conducted on a country basis, while some research fails to apply efficient variables and models, and these are significant issues in terms of policy ramifications. Therefore, the current study examines and applies significant variables that could improve insight on economic performance in terms of remittance inflows and mitigate the negative effects of human flight, notably in the domestic labor sector.

Thus, the following conclusions have been made: Firstly, the result of the panel ARDL in the short term revealed that remittances, human capital flight and brain drain, poverty, corruption, inequality, and trade have significant impacts on sustainable economic growth, as shown in Table 5. While human capital flight and brain drain, poverty, corruption, and inequality negatively affect sustainable economic growth, remittances and trade have positive effects on sustainable economic growth in SSA countries. However, although remittance inflow has a beneficial impact on the economic performance, it is insignificant alone to induce the macroeconomic impact in SSA economies. This could be due to the fact that most households spend their remittance on consumption purposes rather than investing in productive sectors of the economy.

The EC term produced the correct coefficient of -0.266 and a corresponding probability value of 0.0123 . Therefore, returning to the long-term equilibrium condition will take at least four years on average, unless regulatory authorities of the selected SSA countries' such as government agencies and ministries implement active policies and programs that offer opportunities for decent work, wages, and favorable labor market participation for all who wish to seek employment, and also provide traceable channels for remittance inflows into their countries and make the remittance system easy to access as well as policies that will prevent human flight and brain drain. Therefore, for the selected SSA economies' SDGs targets to be achieved, remittances must account for at least a $26 \%$ share of the yearly inflow to overcome the persistent human capital flight and other negative indicators affecting the SSA region. Overall, the result from the Wald coefficient restrictions revealed evidence of a combined effect of our variables of interest on sustainable economic growth in SSA, and this finding makes sense in light of the recent migrant outflow from SSA, as evidenced by the 2019 World Bank report on SSA.

The study concludes that SSA can achieve the SDGs targets for decent work, wages, the labor market, and economic growth, particularly upon formalizing the flow of remittance into the mainstream financial system and providing a yardstick on curbing the persistent human capital flight and brain drain in SSA by 2030, since the restoration to long-term convergence is reasonable (i.e., approximately $26.6 \%$ ) and will take four years, which is less than the nine years remaining to reach the target. 
Therefore, policymakers in SSA countries should focus on institutional changes to eliminate corruption, poverty, and income inequality in order to limit capital flight and brain drain from the region. Additionally, they must stabilize their economic and political environments in order to facilitate foreign trade and investment and boost export, because the total trade value has a positive and significant impact on growth.

Policies can promote the likelihood of both high- and low-skilled migrants sending remittance by improving the channels used for remittance and strengthening cooperation between the original and destination countries, both in terms of information sharing regarding potential needs and the destination countries' labor market. This can lead to higher remittance inflows in SSA, which will increase the chances of achieving the Sustainable Development Goals (SDGs-8) target.

The research limitations include the absence of qualitative data primarily from engagement with the recipients of remittance and the diasporas who sent remittance, as well as migrants, to provide inferential policies. Therefore, we instead used secondary data in the analysis for comparative panel studies. Despite the use of certain indicators and the error term $\left(E_{t}\right)$ in the model used to establish the reliability, it is likely that other variables such as official development assistance, foreign direct investment, and population growth could improve our results in the study. Therefore, further research should focus on remittance, human capital flight, and brain drain in the presence of new variants of Covid-19 such as delta and omicron. Therefore, we can create space for opportunities, discussion, and knowledge of the severity and benefits of the subject of analysis.

Author Contributions: Conceptualization, H.O., M.A.M.U., B.Ç. and U.S.A.; methodology, M.A.M.U. H.O., B.Ç. and U.S.A.; data curation M.A.M.U., B.Ç. and H.O.; investigation, H.O., U.S.A., B.Ç. and M.A.M.U.; writing-original draft, H.O., M.A.M.U., B.Ç. and U.S.A.: writing-review and editing, H.O., M.A.M.U., B.Ç. and U.S.A. All authors have read and agreed to the published version of the manuscript.

Funding: This research received no external funding.

Institutional Review Board Statement: Not applicable.

Informed Consent Statement: Not applicable.

Data Availability Statement: The data are available on request at the Near East University from the corresponding author.

Conflicts of Interest: The authors declared no conflict of interest.

\section{References}

1. Egbulonu, A.J.; Bhattarai, K. Determinants of Capital Flight: New Panel Evidence from Sub-Saharan Africa (SSA). J. Dev. Econ. Financ. 2020, 1, 255-287. Available online: www.arfjournals.com (accessed on 2 December 2021).

2. Sommarribas, A.; Sheridan, A. The impact of COVID-19 in the migration area (EMN OECD UMBRELLA INFORM); European Migration Network: Brussels, Belgium, 2021.

3. World Bank. Global Economic Prospects 2007; World Bank: Washington, DC, USA, 2007.

4. World Bank. Global Economic Prospects 2006: Economic Implications of Remittances and Migration; World Bank: Washington, DC, USA, 2006.

5. UNECA. Brain Drain and Capacity Building in Africa. In Proceedings of the Regional Conference on Brain Drain and Capacity Building in Africa, Aide Memoir, Addis Ababa, Ethiopia, 22-24 February 2000.

6. Mccormick, M. The African Diaspora Network Gives Africans Living Abroad a Pathway to Invest at Home. Forbes. Available online: https://www.forbes.com/sites/meghanmccormick/2020/03/16/theafricandiaspora-networkgivesAfricans-livingabroad-a-pathway-to-invest-at-home/ (accessed on 10 November 2021).

7. Rodima-Taylor, D. African Diaspora and Remittances; Boston University Center for Finance, Law \& Policy: Boston, MA, USA, 2015; Available online: https:/ / www.bu.edu/africa/files/2016/11/pBoston-University-Report-African-Diaspora-andRemittances.pdf (accessed on 20 December 2021).

8. UNCTAD. UNCTAD Statistics. 2019. Available online: https:/unctad.org (accessed on 20 December 2020).

9. Bredtmann, J.; Martínez Flores, F.; Otten, S. Remittances and the brain drain: Evidence from microdata for Sub-Saharan Africa. J. Dev. Stud. 2019, 55, 1455-1476. [CrossRef] 
10. Popogbe, O.; Adeosun, O.T. Empirical analysis of the push factors of human capital flight in Nigeria. J. Hum. Appl. Soc. Sci. 2020, 4, 3-20. [CrossRef]

11. Boger, J. African Universities as Employers of Returning Graduates from Germany: The Example of Ghana and Cameroon. In Geographies of the University; Springer: Cham, Switzerland, 2018; pp. 541-565. ISBN 978-3-319-75593-9. [CrossRef]

12. The World Bank. Record High Remittances Sent Globally in 2018; Washington Press Release: Washington, DC, USA, 2019; Available online: https:/ / www.worldbank.org/en/news/press-release/2019/04/08/record-high.remittancessentglobally-in2018 (accessed on 20 October 2021).

13. Norglo, B.E.K.; Goris, M.; Lie, R.; Ong'ayo, A.O. The African diaspora's public participation in policy-making concerning Africa. Diaspora Stud. 2016, 9, 83-99. [CrossRef]

14. Adepoju, A. International Migration and Development in Sub-Saharan Africa. In The Routledge Handbook of African Demography; Routledge: London, UK, 2022; pp. 573-588.

15. Firsing, S. How Severe Is Africa's Brain Drain? LSE Blog. 2016. Available online: https://blogs.lse.ac.uk/africaatlse/2016/01/18 /how-severe-is-Africa $\backslash \mathrm{T} 1 \backslash$ textquoterights-brain-drain/ (accessed on 10 December 2021).

16. Ehrhart, H.; Le Goff, M.; Singh, R.J. Does migration foster exports? In Evidence from Africa Technical Report; The World Bank: Washington, DC, USA, 2014.

17. African Economic Outlook. Entrepreneurship and industrialization. In African Development Bank; OECD Development Centre, the United Nations Development: Boston, MA, USA, 2017.

18. Council of Europe. Migration and Co-Development: Social Remittances of the African Diasporas in Europe; North-South Center of the Council of Europe: Lisbon, República Portuguesa, 2006.

19. Levitt, P.; Lamba-Nieves, D. Social remittances revisited. J. Ethn. Migr. Stud. 2011, 37, 1-22. [CrossRef]

20. Eckstein, S.; Najam, A. How Immigrants Impact Their Homelands; Duke University Press: Durham, NC, USA, 2013.

21. Okafor, C.; Chimereze, C. Brain drain among Nigerian nurses: Implications to the migrating nurse and the home country. Int. J. Res. Sci. Innov. 2020, 7, 15-21.

22. Thinh, H. Migration and education in Vietnam: Opportunities and challenges. Adv. Sci. Lett. 2017, 23, 2166-2168. [CrossRef]

23. Light, I.; Bhachu, P.; Karageorgis, S. Migration networks and immigrant entrepreneurship. In Immigration and Entrepreneurship; Routledge: London, UK, 2017.

24. Orji, A.; Agu, C. Analysis of migration, regional characteristics, and socioeconomic outcomes in developing economies: Empirical evidence from Nigeria. J. Int. Migr. Integr. 2018, 19, 565-581. [CrossRef]

25. Lemmermann, D.; Riphahn, R. The causal effect of age at migration on youth educational attainment. Econ. Educ. Rev. 2018, 63, 78-99. [CrossRef]

26. Dako-Gyeke, M. Exploring the migration intentions of Ghanaian youth: A qualitative study. J. Int. Migr. Integr. 2016, 17, 723-744. [CrossRef]

27. Ratha, D.K.; De, S.; Kim, E.J.; Plaza, S.; Seshan, G.K.; Yameogo, N.D. COVID-19 crisis through a migration lens. Migr. Dev. Brief 2020, 32, 1-15.

28. World Bank. World Development Report 2021: Data for Better Lives; World Bank: Washington, DC, USA, 2021; Available online: https:/ / openknowledge.worldbank.org/handle/10986/35218 (accessed on 30 November 2021).

29. Davar, M. COVID-19 Impact on Migrants and Remittance Industry. 2020. Available online: https://www.iamtn.org/impactofcovid19 (accessed on 20 December 2021).

30. Asare, J.; Gebrewolde, M.; Saab, M.; Sandi, N.; Sili, L.; Wilkinson, N.; Yang, D. Remittances in the Time of COVID-19: Challenges and Opportunities for Growth in Developing countries. Policy Brief. Int. Growth Centre 2020. Available online: www.theigc.org/ publication/remittances-in-the-timeof-covid-19/ (accessed on 15 November 2021).

31. Ita, E. Human development in Nigeria. Int. J. Afr. Asian Stud. 2020, 61, 40-49.

32. Okunade, S. Gargantuan out-migration: An emerging culture among youths in Nigeria. IPPA Public Policy Pap. 2019, 1, 1-24. Available online: www.ippapublicpolicy.org/file/paper/5d0a2d20b3a36.pdf (accessed on 30 September 2021).

33. Komolafe, J. Nigerian migration to Ireland: Movements, motivations, and experiences. IrishGeography 2008, 41, $225-241$. [CrossRef]

34. Akanle, O.; Fayehun, O.; Adejare, G.; Orobome, O. International migration, kinship networks, and social capital in South-Western Nigeria. J. Borderl. Stud. 2019, 1, 1-14.

35. Amrevurayire, E.; Ojeh, V. Consequences of Rural-Urban migration on the source region of Ughievwen Clan, Delta state Nigeria. Eur. J. Geogr. 2016, 7, 42-57.

36. Onogbosele, D.; Adenuga, O. Challenges of human capital formation in Nigeria: A descriptive analysis. Lafia J. Econ. Manag. Sci. 2018, 3, 75-101.

37. Tabassum, S.; Quddoos Yaseen, A.; Sardar, M.A. The relationship between capital flight, labor migration, and economic growth. Eur. Online J. Nat. Soc. Sci. 2017, 6, 594-600.

38. Perpetua, O.N.; Chimaobi, I.C.; Jackson, J. Economic recession and migration: The case of Nigeria. Nnamdi Azikiwe Univ. Awka J. Sociol. 2019, 6, 1-12.

39. Basar, U.A.; Ab Hamid, M.F.; Asid, R.; Sulaiman, W.F.W.; Bahri, E.N.A.; Sulaiman, N.F.C.; Ramli, N. An Analysis of Capital Flight Risk: Case for Human Capital in Inclusive Growth. In Issues and Challenges in the Malaysian Economy; Emerald Publishing Limited: Bingley, UK, 2019; pp. 14-31. [CrossRef] 
40. El-Khawas, M.A. Brain drain: Putting Africa between a rock and a hard place. Mediterr. Q. 2004, 15, 37-56. [CrossRef]

41. Kaba, A. The status of Africa's emigration brain drain in the 21st century. West. J. Black Stud. 2011, 35, $187-207$.

42. Kamau, A.W.; Kimenyi, M.S. More than Just Sending Money Home: Engaging the Diaspora as a Priority for Africa's Development. Foresight Africa: Top Priorities for the Continent in 2013. The Brookings Institution/Africa Growth Initiative. 2013. Available online: www.brookings.edu/foresight-africa (accessed on 20 December 2021).

43. Sørensen, N.N. Revisiting the migration-development nexus: From social networks and remittances to markets for migration control. Int. Migr. 2012, 50, 61-76. [CrossRef]

44. Délano, A.; Gamlen, A. Comparing and theorizing state-diaspora relations. Political Geogr. 2014, 41, 43-53. [CrossRef]

45. Gamlen, A. Diaspora Engagement Policies: What Are They, and What Kinds of States Use Them? COMPAS Working Papers; Centre on Migration, Policy and Society, University of Oxford: Oxford, UK, 2006; Volume wp0632.

46. Gamlen, A.; Cummings, M.; Vaaler, P.M.; Rossouw, L. Explaining the Rise of Diaspora Institutions; IMI Working Paper 78; University of Oxford, International Migration Institute: Oxford, UK, 2013.

47. World Bank. COVID-19 Crisis through a Migration Lens. Migration and Development Brief 32 [online]; The World Bank: Washington, DC, USA, 2020; Available online: https://openknowledge.worldbank.org/bitstream/handle/10986/33634/COVID-19 -CrisisThrough-a-Migration-Lens.pdf?sequence $=5$ (accessed on 20 November 2021).

48. Hong, A.; Anna, K. Strengthening the Migration Development Nexus through Improved Policy and Institutional Coherence. KNOMAD Working Paper 15. 2016. Available online: https:/ /www.knomad.org/publication/strengthening-migrationdevelopmentnexus-through-improved-policy-and-institutional (accessed on 30 October 2021).

49. Portes, A.; Borocz, J. Contemporary immigration: Theoretical perspectives on its determinants and mode of Incorporation. Int. Migr. Rev. 1989, 23, 606-630. [CrossRef] [PubMed]

50. Ajide, K.B.; Alimi, O.Y. Political instability and migrants' remittances into sub-Saharan Africa region. GeoJournal 2019, 84, 1657-1675. [CrossRef]

51. Oyinlola, M.A.; Adedeji, A. Human capital, financial sector development and inclusive growth in sub-Saharan Africa. Econ. Chang. Restruct. 2019, 52, 43-66. [CrossRef]

52. Buchan, J.; Parkin, T.; Sochalski, J. Interactional Nurse Mobility: Trends and Policy Implications; World Health Organization: Geneva, Switzerland. Available online: http://whqlibdoc.who.int/hq/2003/WHOEIP_OSD_2003.3.pdf (accessed on 10 June 2017).

53. Mohamed, M.A.; Abdul-Talib, A.N. Push-pull factors influencing international return migration intentions: A systematic literature review. Int. Return Migr. Intent. 2020, 14, 231-246. [CrossRef]

54. Harris, J.; Todaro, M. Migration, unemployment, and development: A two-sector analysis. Am. Econ. Rev. 1970, 60, 126-142. [CrossRef]

55. Cai, Q. Migrant Remittances and Family Ties: A case Study in China. Int. J. Popul. Geogr. 2003, 9, 471-483. [CrossRef]

56. Taylor, E.J. The new economics of labor migration and the role of remittances in the migration process. Int. Migr. 1999, 37, 63-88. [CrossRef]

57. Elmi, M.A.; Ngwenyama, O. Examining the use of electronic money and technology by the diaspora in international remittance system: A case of Somali remittances from Canada. Electron. J. Inf. Syst. Dev. Ctries. 2020, 86, e12138. [CrossRef]

58. Bonga, W.G. Exploring the Level of Diaspora Remittances Flows in Zimbabwe. Glob. Sci. J. 2020, 8, $1525-1531$.

59. Maddala, G.S. Introduction to Econometrics, 3rd ed.; Wiley: New York, NY, USA, 2001; ISBN 0-471-49728-2.

60. Halicioglu, F. Residential electricity demand dynamics in Turkey. Energy Econ. 2007, 29, 199-210. [CrossRef]

61. Pesaran, H.; Shin, Y. An autoregressive distributed lag modelling approach to cointegration in econometrics and economic theory in the 20th Century. In The Ragnar Frisch Centennial Symposium; Cambridge University Press: Cambridge, UK, 1999 ; pp. $371-413$.

62. Pesaran, M.H.; Yongcheol, S.; Richard, J.S. Bounds testing approaches to the analysis of level relationships. J. Appl. Econom. 2001, 16, 289-326. [CrossRef]

63. Harris, R.; Robert, S. Applied Time Series Modelling and Forecasting; Wiley: West Sussex, UK, 2003.

64. Jalil, A.; Ma, Y. Financial development and economic growth: Time series evidence from Pakistan and China. J. Econ. Coop. Among Islamic Ctries. 2008, 29, 29-68.

65. Ali, H.S.; Law, S.H.; Zannah, T.I. Dynamic impact of urbanization, economic growth, energy consumption, and trade openness on CO2 emissions in Nigeria. Environ. Sci. Pollut. Res. 2016, 23, 12435-12443. [CrossRef]

66. Aristei, D.; Martelli, D. Sovereign bond yield spreads and market sentiment and expectations: Empirical evidence from Euro area countries. J. Econ. Bus. 2014, 76, 55-84. [CrossRef]

67. Hsiao, C.; Pesaran, M.H.; Lahiri, K.; Lee, L.F. (Eds.) Analysis of Panels and Limited Dependent Variable Models; Cambridge University Press: Cambridge, UK, 1999; ISBN 0-521-63169-6.

68. Levin, A.; Lin, C.-F.; Chu, C.-S.J. Unit root tests in panel data: Asymptotic and finite-sample properties. J. Econom. 2002, 108, 1-24 [CrossRef]

69. Ramos-Herrera, M.D.C.; Prats, M.A. Fiscal Sustainability in the European Countries: A Panel ARDL Approach and a Dynamic Panel Threshold Model. Sustainability 2020, 12, 8505. [CrossRef]

70. Oteng-Abayie, E.F.; Awuni, P.A.; Adjeidjei, T.K. The Impact of Inward Remittances on Economic Growth in Ghana. Afr. J. Econ. Rev. 2020, 8, 49-65.

71. Aliyu, U.S.; Ozdeser, H.; Çavuşoğlu, B.; Usman, M.A. Food Security Sustainability: A Synthesis of the Current Concepts and Empirical Approaches for Meeting SDGs. Sustainability 2021, 13, 11728. [CrossRef] 
72. Shuaibu, U.A.; Usman, M.A.; Çavuşoğlu, B. The Nexus among Competitively Valued Exchange Rates, Price Level, and Growth Performance in the Turkish Economy; New Insight from the Global Value Chains. J. Risk Financ. Manag. 2021, 14, 528. [CrossRef]

73. Iken, O.; Abakporo, U.; Ayobami, O.; Attoye, T. COVID-19: Travel health and the implications for sub-Saharan Africa. Travel Med. Infect. Dis. 2020, 35, 101645. [CrossRef] [PubMed]

74. Leal Filho, W.; Azul, A.M.; Brandli, L.; Lange Salvia, A.; Wall, T. (Eds.) . Decent Work and Economic Growth; Springer International Publishing: Cham, Switzerland, 2020. 